\title{
Ceratopogonidae (Diptera: Nematocera) of the piedmont of the Yungas forests of Tucumán: ecology and distribution
}

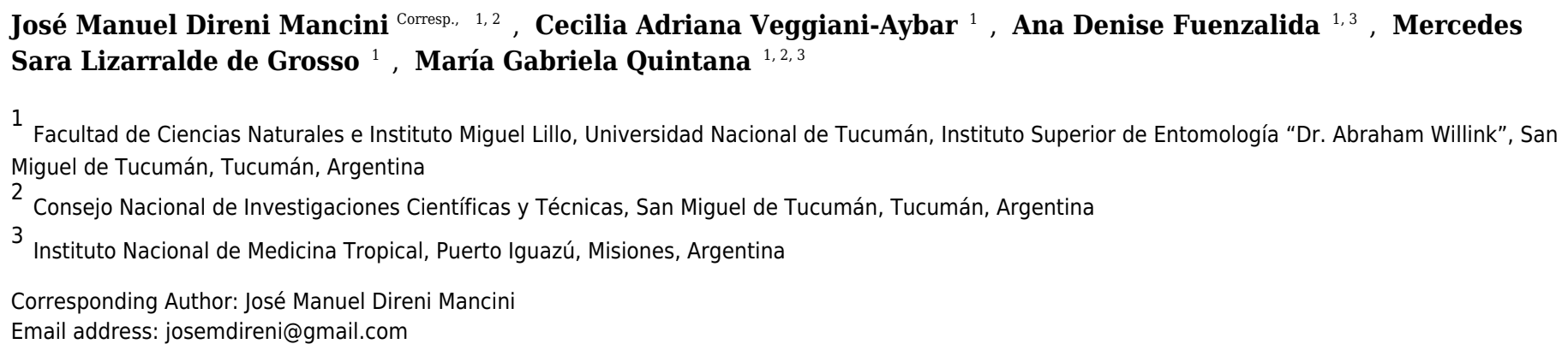

Within of the Ceratopogonidae family, many genera transmit numerous diseases to humans and animals, while others are important pollinators of tropical crops. In the Yungas ecoregion of Argentina, previous systematic and ecological research on Ceratopogonidae focused on Culicoides, since they are the main transmitters of mansonelliasis in northwestern Argentina; however, few studies included the genera Forcipomyia, Dasyhelea, Atrichopogon, Alluaudomyia, Echinohelea, and Bezzia Therefore, the objective of this study was to determine the presence and abundance of Ceratopogonidae in this region, their association with meteorological variables, and their variation in areas disturbed by human activity. Monthly collection of specimens was performed from July 2008 to July 2009 using CDC miniature light traps deployed for two consecutive days. A total of 360 specimens were collected, being the most abundant Dasyhelea genus (48.06\%) followed by Forcipomyia (26.94\%) and Atrichopogon (13.85\%). Bivariate analyses showed significant differences in the abundance of the genera at different sampling sites and climatic conditions, with the summer season and El Corralito site showing the greatest abundance of specimens. Accumulated rainfall was the variable that related the most to the abundance of Culicoides (10.56\%), while temperature was the most closely related variable to the abundance of Forcipomyia, Dasyhelea, and Atrichopogon. 
1 Ceratopogonidae (Diptera: Nematocera) of the piedmont Yungas forests of Tucumán:

2 ecology and distribution

3

4 José M. Direni-Mancini ${ }^{1,3}$, Cecilia A.Veggiani-Aybar ${ }^{1}$, Ana D. Fuenzalida ${ }^{1,2}$, Mercedes S.

5 Lizarralde de Grosso ${ }^{1}$ and María G. Quintana ${ }^{1,2,3}$

6

7

8 Corresponding Author:

$9 \quad$ José Manuel Direni Mancini

Instituto Superior de Entomología "Dr. Abraham Willink”, Facultad de Ciencias Naturales e

Instituto Miguel Lillo, Universidad Nacional de Tucumán y Consejo Nacional de Investigaciones Científicas y Técnicas (CONICET).

Miguel Lillo 205, San Miguel de Tucumán, Argentina. 
25 ABSTRACT

Within the Ceratopogonidae family, many genera transmit numerous diseases to humans and animals, while others are important pollinators of tropical crops. In the Yungas ecoregion of Argentina, previous systematic and ecological research on Ceratopogonidae focused on Culicoides, since they are the main transmitters of mansonelliasis in northwestern Argentina; however, few studies included the genera Forcipomyia, Dasyhelea, Atrichopogon, Alluaudomyia, Echinohelea, and Bezzia. Therefore, the objective of this study was to determine the presence and abundance of Ceratopogonidae in this region, their association with meteorological variables, and their variation in areas disturbed by human activity. Monthly collection of specimens was performed from July 2008 to July 2009 using CDC miniature light traps deployed for two consecutive days. A total of 360 specimens were collected, and Dasyhelea (48.06\%) was the most abundant, followed by Forcipomyia (26.94\%) and Atrichopogon (13.85\%). Bivariate analyses showed significant differences in the abundance of the genera at different sampling sites and climatic conditions, with the summer season and El Corralito site showing the greatest abundance of specimens. Accumulated rainfall was the variable that related the most to the abundance of Culicoides $(10.56 \%)$, while temperature was the most closely related variable to the abundance of Forcipomyia, Dasyhelea, and Atrichopogon.

\section{INTRODUCTION}

Ceratopogonidae family constitutes a much diversified and globally widespread group of Culicomorpha. At the present, it is represented by 6267 species and 111 living genera grouped in 
474 subfamilies (Ceratopogoninae, Leptoconopinae, Forcipomiinae and Dasyheleinae) (Borkent, 48 2016).

Austroconops Wirth \& Lee (only one australian species), Culicoides Latreille,

Leptoconops Skuse and Forcipomyia Meigen (subgenus Lasiohelea) are implied in the

transmission of arbovirus, parasites and protozoa that cause diseases both in humans and other animals (Mellor et al., 2000; Borkent \& Spinelli, 2007; Veggiani Aybar et al., 2010a, 2015a).

Other genera proportion important services in ecological systems, such as Forcipomyia and

Dasyhelea Kieffer, to a lesser extent Atrichopogon Kieffer, Culicoides and Stilobezzia Kieffer which are potential pollinators of different crops, such as cocoa (Theobroma cacao Linnaeus), rubber (Hevea brasiliensis Müller Argoviensis), and mango (Mangifera indica Linnaeus) in tropical regions (Borkent \& Spinelli, 2007; Bravo et al., 2011); while some species of Forcipomyia and Culicoides are ectoparasites of insects, sucking the lymph of lepidopterans, coleopterans, odonata, phasmids, neuropterans and hemipterans (Borkent, 2004). In turn, Ceratopogon Meigen, Bezzia Kieffer, Brachypogon Kieffer, Monohelea Kieffer, Serromyia Meigen, Stilobezzia Kieffer, Palpomyia Meigen (Bernotienė, 2006), Allohelea Kieffer (Werner \& Kampen, 2010), Ceratoculicoides Wirth \& Ratanaworabhan (Huerta \& Borkent, 2005), Alluaudomyia Kieffer and Echinohelea Macfie (Borkent \& Spinelli, 2007) are predators of small flying insects of the same or smaller size. However, the relevance of this family is given by Culicoides genus, which is vector of the Bluetongue virus, Schmallenberg virus, Epizootic Hemorrhagic Disease virus, African Horse Sickness virus, Akabane virus and Bovine Ephemeral Fever virus, among others, affecting ovine and bovine cattle (Mellor et al., 2000; Borkent, 2004; Carpenter et al., 2013); and of the transmission to humans of the Oropouche virus, Mansonella nematode and Leishmania trypanosomatidae (Mellor et al., 2000; Ronderos et al., 2003; 
epidemiologic relevance as a vector of filarial Mansonella ozzardi (Shelley \& Coscarón, 2001;

Culicoides spp. and the influence of meteorological variables (temperature, accumulated rainfall,

humidity, etc) in their abundance, behavior and distribution, and the interactions between

pathogens and vectors (Veggiani Aybar et al., 2010a, 2011, 2012, 2015a); however, such aspects have not been studied in other families of Ceratopogonidae of the area. Therefore, the objective of this study was to determine the presence and abundance of the main genera of Ceratopogonidae in piedmont forests of Tucumán province, and to evaluate the effect of meteorological variables in their distribution.

\section{Characterization of the study area}


94 (Griseb.) Burkart, while undergrowth vegetation is dominated by Piper tucumanum C. DC.,

95 Eugenia uniflora L., Urera baccifera (L.) Gaudich., and Solanum riparium Pers. Many species

96 of lianas of Bignoniaceae, Ulmaceae and Amarantaceae families, and vascular plants with

97 epiphyte habits, belonging to Polipodaceae, Asplaniaceae, Piperaceae and Bromeliaceae are also

98 frequent. In open areas, the most common arboreal species are Tipuana tipu (Benth.) Kuntze,

99 Jacaranda mimosifolia D. Don, Anadenanthera colubrina var. cebil (Griseb.), Tabebuia

100 avellanedae Lorentz ex Griseb., Heliocarpus popayanensis Kunth, Fagara coco (Gillies ex

101 Hook. \& Arn.) Engl., Tecoma stans (L.) Juss. ex Kunth, Salix humboldtiana Willd., and Carica

102 quercifolia (A. St. Hil.) Hieron (Grau, 2005; Brown et al., 2006).

103 Despite the climatic variability, rises in mean annual rainfall in the last years have been

104 detected, as a consequence of the replacement of native vegetation and the expansion of

105 extensive crops (sugarcane, tobacco, fruit trees, among others), which provoked important

106 modifications in the landscape (Brown \& Malizia, 2004).

\section{Collecting sites}

108 Based on environmental and socio-demographic characteristics and operational accessibility, a

109 total of 10 households were selected for sampling (five paired sampling sites, Fig. 1).

Peridomestic sites were georeferenced and characterized through an ad-hoc survey, using

111 the criteria of "worst scenario", an operational definition for the site within the study area. The

112 methodology has been employed for the study of Phlebotominae subfamily and defines sites with

113 features such as shade presence, moist soils, organic detritus, proximity to patches of dense

114 vegetation, density, quality and accessibility of sources of blood supply intake, no interference from

115 external lights, and epidemiological records, among others; with higher probability of finding the

116 specimens of interest. For spatial analyses of environmental-driven changes in the abundance of 
117 vectors, this methodology presents more biological significance than a spatial centroid

118 (Feliciangeli et al., 2004; Correa Antonialli et al., 2007; Salomón, 2007).

119 The following sampling sites were selected: El Corralito (EC1: 27³7’25.2”S;

120 6542’59.9'W and EC2: 27³7'56.9”S; 6541'23.9”W), El Badén (EB1: 27³7'13.9”S:

121 6541’39.6”W and EB2: 27³7’27.2”S; 6541’32.0”W), Yánima (YA1: 27³7’58.8”S;

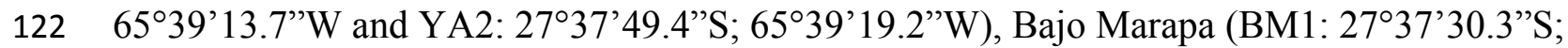

$12365^{\circ} 38^{\prime} 00.5^{\prime} \mathrm{W}$ and BM2: 27³7'28.4”S; 65³8'07.1”W) and Marapa Central (MC1:

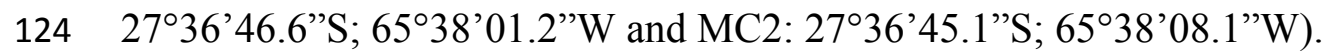

\section{Collection and processing of specimens}

126

127

128

129

130

131

132

133

134

135

136

137

138

Adult specimens were collected monthly from July 2008 to July 2009 with CDC-like light minitraps (Sudia \& Chamberlain, 1962), placed from 18:00 to 07:00 during two consecutive days. In the laboratory, specimens were separated from other insects and placed in properly labeled Eppendorf tubes containing 70\% alcohol for preservation. The identification of adults was performed following the taxonomic keys of Spinelli \& Wirth (1993) and Spinelli et al. (2005).

\section{Data analysis}

The obtained data were entered into an Excel spreadsheet and then were analyzed using InfoStat 2016e version statistical software (Di Rienzo et al., 2016). The abundance of each genus by season and sampling site was compared and bivariate statistical analyses (chi-squared test) were applied. In all cases, Cramer V coefficient was used to measure the association or independence among the considered variables, which takes values between 0 (weak association) to 1 (strong association). Posteriorly, multiple regression analyses (stepwise method) were performed (Balzarini et al., 2008). The independent variables were included in the multiple linear regression 
139 analyses but the variables that contributed the least to the explanation were eliminated one by

140 one. All statistical tests were considered significant at $\mathrm{P} \leq 0.05$.

141 Mean abundance values (dependent variable) were standardized using $\log (\mathrm{n}+2)$. The

142 meteorological variables (independent variables) considered in this study were: temperature (T),

143 accumulated rainfall (R), relative humidity (Rh), wind speed (Ws) and maximum wind speed

144 (maxWs), which were monthly averaged. Meteorological data were obtained from the Agro-

145 meteorology department of Agroindustrial Experimental Station Obispo Colombres, Tucumán

146 province.

147

148

\section{RESULTS}

149 A total of 360 adult Ceratopogonidae specimens belonging to Alluaudomyia, Atrichopogon,

Bezzia, Culicoides, Dasyhelea, Echinohelea and Forcipomyia genera were collected.

Of these seven genera, the most abundant were Dasyhelea $(48.06 \%)$, followed by

152

153

154

155

156

157

158

159

160

161

Forcipomyia (26.94\%) and Atrichopogon (13.61\%) which represented 90\% of the total specimens, while the other percentage corresponded to Culicoides (10.56\%), Alluaudomyia, Echinohelea and Bezzia $(0.28 \%$, respectively) (Table 1$)$.

\section{Chi-squared Analysis}

When considering the total abundance of specimens per sampling site, a higher abundance was observed at El Corralito (EC, 40.83\%), followed by Marapa Central (MC, 18.61\%) and El Badén (EB, 17.78\%). Yánima (YA) and BajoMarapa (BM) exhibited similar abundances (11.67\% and $11.11 \%$, respectively).

For the bivariate analyses, the four more abundant genera were considered. Significant differences among sampling sites, seasons and genera were observed (Table 2, Table 3). 
163 (February), and at El Corralito, El Baden, Bajo Marapa and Marapa Central sites; followed by

164 Forcipomyia, with a higher abundance in spring (October) and at Yánima site. In turn,

165 Atrichopogon was the most abundant genus in autumn (April), winter (July) and summer (March)

166 at El Corralito, El Baden and Bajo Marapa sites; while Culicoides was more abundant in spring

167 (December) and at Yánima and Marapa Central sites. Finally, in all sampling sites, there was an

168 increase in the abundance of the seven genera compared to that of warmer seasons along the

169 study period.

170 Regression analyses

171 The multiple regression analyses allowed obtaining the following descriptive models: for

172 Culicoides genus, the regression analysis between the abundance of specimens and

173 meteorological variables determined a significant correlation with accumulated rainfall $\left(\mathrm{R}^{2}=\right.$

174 0.46; $\mathrm{P}<0.0157$ ) (Fig. 2A); while temperature was strongly related to the abundance of

175 Forcipomyia $\left(\mathrm{R}^{2}=0.32 ; \mathrm{P}<0.0561\right)$ (Fig. 2B), Dasyhelea $\left(\mathrm{R}^{2}=0.59 ; \mathrm{P}<0.0035\right)($ Fig. $2 \mathrm{C})$ and

176 Atrichopogon $\left(\mathrm{R}^{2}=0.42 ; \mathrm{P}<0.0221\right)$ (Fig. 2D).

\section{Partial and predicted residuals}

178 From the partial residuals (Fig. 3 A-D), a positive linear relation was observed between

179 Culicoides abundance and accumulated rainfall, while the same relation was observed between

180 temperature and the abundance of Forcipomyia, Dasyhelea and Atrichopogon, although less

181 marked in the latter. In addition, standardized residuals versus predicted (Figs. 4 A-D)

182 determined a dispersed point cloud, which indicated that the used model was valid for three of

183 the four studied genera. Finally, the trend of the points of Atrichopogon was negative, indicating

184 that the model was unsuitable for the regressor variable retained by the model. 


\section{DISCUSSION}

186 In the present study, the abundance of Ceratopogonidae genera in an area of Yungas which has

187 been strongly modified and transformed by humans was registered.

The abundance of specimens varied among seasons and study sites, with a differential pattern observed mainly in the warm season and at El Corralito, Marapa Central, El Badén, Yánima and Bajo Marapa sites. Such differences in abundance could be due to that suggested by Borkent \& Spinelli (2007), who mentioned that most members of Ceratopogonidae family require of environments with high humidity for their development. For this family, the humid season is more suitable to complete their life cycle; since many of the genera go through winter in the later larval stage, similarly to what occurs at temperate regions of the north. Also, the available food sources in the study area, such as barnyard animals (chicken, pigs and horses) or humans in the case of hematophagous genera; and vegetal food sources such as flowers and fruits for pollinators should be considered; as well as the presence of suitable environments for the development of immature stages, which can be aquatic, semi-aquatic or terrestrial. al. (2010a, 2012) determined population peaks during summer, autumn and spring to a lesser

201

202 203 extent in Tucumán province, and during spring and summer but gradually diminishing towards winter in Salta province; in agreement with in the findings of the present study.

Among the collected genera, Culicoides and Forcipomyia exhibit public health significance; the former excelling as the main vectors of $M$. ozzardi in the region. However, Forcipomyia genus (Lasiohelea subgenus), scarcely studied in the province, might be involved not only in the transmission of mansonelliasis but also in the transmission of other viruses and protozoa, which would represent a potential risk for the region, especially due to its high 
208 abundance found both in the present study as well as in other studies carried out in northwestern 209 Argentina (Veggiani Aybar et al., 2010b, 2015a). On the other hand, it is worth mentioning that 210 in the last years, infection of Culicoides species with Leishmania infantum (LV) in the Old World

211 was determined (Seblova et al., 2012, Slama et al., 2014), parasite that causes visceral leishmaniasis (VL)

212 worldwide (WHO, 2010). In the study area, Salomon et al. (2006) determined the spatial and

213 temporal distribution of risk and the regional epidemiological trends of tegumentary

214 leishmaniasis (TL), a type of Leishmania which is endemic of the Yungas of Argentina. The here 215 presented data in addition to other studies carried out in the area (Veggiani Aybar et al., 2010a, 2162012,2015 b) represent a starting point for continuing with the study of this genus in areas where 217 its distribution matches that of the family Psychodidae, the main vectors of this parasite in the 218 region (Córdoba Lanús \& Salomón, 2002; Salomón et al., 2006; Quintana et al., 2012).

219 Regarding the influence of meteorological variables over the abundance of genera of medical and veterinarian importance, accumulated rainfall and temperature were significantly important for Culicoides and Forcipomyia, respectively. In relation to this, Veggiani Aybar et al., (2010b, 2011) observed that in Tucumán province, the higher incidence of Culicoides was mainly associated with accumulated rainfall, followed by relative humidity, wind speed and mean temperature, although these last two variables were not significant in the present study. On Culicoides and temperature and relative humidity (Veggiani Aybar et al., 2012). In addition, several authors have informed the strong relation between temperature, accumulated rainfall and

228 humidity to the abundance of Culicoides in Brazil, due to the influence of these meteorological 229 variables over the life cycles of the species or the alteration in their breeding sites (Sherlock \& 230 Guitton, 1964; Santos da Silva et al., 2001; De Barros et al., 2007). 

northwestern Argentina are scarce. However, Veggiani Aybar et al. (2010b, 2015b) reported the presence and abundance of these genera and the presence of Brachypogon, Monohelea,

234 Stilobezzia and Clinohelea in the Yungas of Argentina and Bolivia. It is worth mentioning that their role as pollinators of economical important crops has not been evaluated in the region, although several studies in America Latina corroborate it (Kaufmann, 1975; Young, 1983; Bravo

237 et al., 2011; Córdoba et al., 2013). Such background highlights the importance of these genera, 238 not only for natural ecosystems but also for agricultural systems of northwestern Argentina, 239 where a wide variety of fruit crops which might be pollinated by these species is registered.

240 Finally, Bezzia, Echinohelea and Alluaudomyia, which are predators of insects, might act as 241 controllers of pests insects associated to crops. emerges from the results of this study, for upgrading the knowledge of both taxonomic and distributional aspects of Ceratopogonidae family, and for evaluating their relevance as disease vectors and pollinators of commercial crops.

\section{ACKNOWLEDGEMENTS}

This study was conducted within the framework of a Federal Productive Innovation Project in Tucumán endemo-epidemic area." 
254

255

256

257

258

259

260

261

262

263

264

265

266

267

268

269

270

271

272

273

274

275

276

\section{REFERENCES}

Balzarini MG, González L, Tablada M, Casanoves F, Di Rienzo JA, Robledo CW. 2008. Infostat. Manual del Usuario, Editorial Brujas, Córdoba, Argentina. 336 pp.

De Barros VLL, Marinho RM, Rebêlo JM. 2007. Ocorrência de espécies de Culicoides Latreille (Diptera: Ceratopogonidae) na área metropolitana de São Luís, Maranhão, Brasil. Caderno de Saúde Pública 23: 2790-2798.

Bernotienè R. 2006. Peculiarities of biting midges (Ceratopogonidae) distribution and biodiversity in forest habitats. Miökininkyste 59: 35-42.

Borkent A. 2004. Ceratopogonidae. Chapter 10, pp. 113-126. In: Marquardt, W. C. (Ed.). Biology of Disease Vectors. 2nd edition. Elsevier Press, Amsterdam, Países Bajos. 785 p.

Borkent A, Spinelli GR. 2007. Neotropical Ceratopogonidae (Diptera: Insecta). In: Adis, J., Arias, J.R., Rueda-Delgado, G.; Wantzen, K.M. (Eds.). Aquatic Biodiversity in Latin America (ABLA), Vol. 4. Pensoft, Sofia-Moscú, 198 p.

Borkent A. 2016. World species of Biting Midges (Diptera:Ceratopogonidae). Salmon Arm, British Columbia, 245 pp. Available at

http://www.inhs.uiuc.edu/research/FLYTREE/CeratopogonidaeCatalog.pdf Last update May 16, 2016. (accessed 12 August 2016).

Bravo JC, Somarriba E, Arteaga G. 2011. Factores que afectan la abundancia de insectos polinizadores del cacao en sistemas agroforestales. Revista de Ciencias Agrícolas 1: 119131.

Brown AD, Grau HR. (Eds.) 1995. Investigación, conservación y desarrollo en selvas subtropicales de montaña. LIEY-Facultad de Ciencias Naturales e Instituto Miguel Lillo, Universidad Nacional de Tucumán. Horco Molle, Tucumán, Argentina, 270 pp. 
277 Brown AD, Malizia LR. 2004. Las selvas pedemontanas de las Yungas. Ciencia Hoy 14 (83):

278

279

280

281

282

283

284

285

286

287

288

289

290

291

292

293

294

295

296

297

298 52-63.

Brown AD, Malizia LR, Lomáscolo T. 2006. Reserva de la Biosfera de las Yungas: armando el rompecabezas entre todos. In: Secretaria Programa sobre El Hombre y la Biosfera, Artículo para el Libro sobre Reservas de la Biosfera de países que integran la Red Iberomab. Fundación ProYungas. Available at http://www.ecopuerto.com/bicentenario/informes/RESERVABIOSFERAYUNGAS.pdf. (accessed 4 April 2016).

Carpenter S, Groschup MH, Garros C, Felippe-Bauer ML, Purse BV. 2013. Culicoides biting midges, arboviruses and public health in Europe. Antiviral Research 100: 102-113.

Córdoba-Lanús E, Salomón OD. 2002. Phlebotominae fauna in the province of Tucumán, Argentina. Revista do Instituto de Medicina Tropical de São Paulo 44 (1): 23-27.

Córdoba C, Cerda R, Deheuvls O, Hidalgo E, Decler KF. 2013. Polinizadores, polinización y producción potencial de cacao en sistemas agroforestales de Bocas del Toro, Panamá. Available at http://repositorio.bibliotecaorton.catie.ac.cr:8080/handle/11554/6677. (accessed 3 March 2016).

Correa-Antonialli SA, Torres TG, Paranhos-Filho AC, Tolezano JE. 2007. Spatial analysis of American Visceral Leishmaniasis in Mato Grosso do Sul State, Central Brazil. Journal of Infectology 54: 509-514.

Di Rienzo JA, Casanoves F, Balzarini MG, Gonzalez L, Tablada M, Robledo CW. InfoStat versión 2016e. Grupo InfoStat, FCA, Universidad Nacional de Córdoba, Argentina. Available at http://www.infostat.com.ar. (accessed 15 March 2016). 
299

300

301

302

303

304

305

306

307

308

309

310

311

312

313

314

315

316

317

318

319

320

321

Feliciangeli MD, Arrivillaga JC, Bravo A, Arias F. 2004. Activity of Lutzomyia pseudolongipalpis and L. longipalpiss. l. (Diptera: Psychodidae) in Venezuela. Parasite 11: 273-278.

Grau HR. 2005. Dinámica de bosques en el gradiente altitudinal de las Yungas Argentinas. Ecología y manejo de los bosques de Argentina. 1-30. Available at http://www.csnat.unt.edu.ar/ed/public/investigacion/biologia/Grau2005_BosquesArgentin os.pdf. (accessed 4 April 2016).

Huerta H, Borkent, A. 2005. A new species and first record of Ceratoculicoides Wirth and Ratanaworabhan from the Neotropical Region and new species and records of Brachypogon Kieffer from Mexico (Diptera: Ceratopogonidae). Folia Entomológica Mexicana 44 (1): 111-119.

Kaufmann T. 1975. Ecology and behavior of cocoa pollinating Ceratoponidae in Ghana, W. Africa. Enviromental Entomology 4 (2): 347-351.

Malizia L, Pacheco S, Blundo C, Brown AD. 2012. Caracterización altitudinal, uso y conservación de las Yungas Subtropicales de Argentina. Revista Ecosistemas 21 (1-2).

Mellor P, Boorman J, Baylis M. 2000. Culicoides biting midges: their role as arbovirus vectors. Annual Review of Entomology 45: 307-340.

Salomón OD. 2007. Estratificación de riesgo de leishmaniasis visceral. Informe preliminar. Ministerio de Salud de la Nación. 80 pp.

Quintana MG, Fernández MS, Salomón OD. 2012. Distribution and abundance of phlebotominae, vectors of leishmaniasis, in Argentina: Spatial and temporal analysis at different scales. Journal of Tropical Medicine: 1-16. http://dx.doi.org/10.1155/2012/652803 
322 Ronderos MM, Spinelli GM, Lager I, Díaz F. 2003. La importancia sanitaria de los jejenes del

323

324

325

326

327

328

329

330

331

332

333

334

335

336

337

338

339

340

341

342

343 género Culicoides (Diptera: Nematocera) en la Argentina. Entomología y Vectores 10 (4): 601-612.

Santos Da Silva C, Felippe-Bauer M, Almeida E, Figueiredo L. 2001. Culicoides (Diptera: Ceratopogonidae) do Estado do Rio de Janeiro, Brasil. I. Regiao Norte: Municipio de campos dos Goytacazes. Entomología y Vectores 8: 349-358.

Salomón OD, Quintana MG, Flores I, Andina AM, Molina S, Montivero L, Rosales I. 2006. Phlebotominae sand flies associated with a tegumentary leishmaniasis outbreak, Tucumán Province, Argentina. Revista da Sociedade Brasileira de Medicina Tropical 39 (4): 341 346.

Seblova V, Sadlova J, Carpenter S, Volf P. 2012. Development of Leishmania Parasites in Culicoides nubeculosus (Diptera: Ceratopogonidae) and Implications for Screening Vector Competence. Journal of Medical Entomology 49 (5): 967-970.

Shelley AJ, Coscaron S. 2001. Simuliid blackflies (Diptera: Simuliidae) and Ceratopogonid midges (Diptera: Ceratopogonidae) as vectors of Mansonella ozzardi (Nematoda: Onchocercidae) in northern Argentina. Memórias do Instituto Oswaldo Cruz 96: 451-458.

Sherlock IA, Guitton N. 1964. Dermatozoonosis by Culicoides bite (Diptera: Ceratopogonidae) in Salvador, State of Bahía, Brazil. II. The bionomics of the Culicoides. Memorias do Instituto Oswaldo Cruz 62: 145-159.

Slama D, Haouas N, Remadi L, Mezhoud H, Babba H, Chaker E. 2014. First detection of Leishmania infantum (Kinetoplastida: Trypanosomatidae) in Culicoides spp. (Diptera: Ceratopogonidae). Parasites and Vectors 7: 1-3. 
344 Spinelli GR, Wirth WW. 1993. Los Ceratopogonidae de la Argentina (Insecta: Diptera). In: Fauna de agua dulce de la República Argentina. Castellano, Z. eds. Buenos Aires. 38 (3): 1-124.

Spinelli GR, Ronderos MM, Diaz F, Marino P. 2005. The bloodsucking biting midges of Argentina (Diptera: Ceratopogonidae). Memórias do Instituto Oswaldo Cruz 100 (2): 137-150.

Sudia WD, Chamberlain RW. 1962. Battery operated light trap, an improved model. Mosquito News 22: 126-129.

Veggiani-Aybar CA, Dantur-Juri MJ, Lizarralde de Grosso M, Spinelli G. 2010a. Species diversity and seasonal abundance of Culicoides biting midges in northwestern Argentina. Medical and Veterinary Entomology 24: 95-98.

Veggiani-Aybar CA, Dantur-Juri MJ, Lizarralde de Grosso M, Spinelli G. $2010 b$. Diversidad e influencia de factores climáticos sobre los jejenes (Diptera: Ceratopogonidae) del NOA. I Congreso Latinoamericano (IV Argentino) de la Conservación de la Biodiversidad. SM Tucumán, Tucumán.

Veggiani-Aybar CA, Dantur-Juri MJ, Lizarralde de Grosso M, Spinelli G. 2011. Spatial and temporal distribution of Culicoides insignis and Culicoides paraensis in the subtropical mountain forest of Tucumán, northwestern Argentina. Florida Entomologist 94 (4): 1018-1025.

\section{Veggiani-Aybar CA, Dantur-Juri MJ, Santana M, Lizarralde de Grosso M, Spinelli G.} 2012. The spatio-temporal distribution patterns of biting midges of the genus Culicoides in Salta province, Argentina. Journal of Insect Science 12 (145): 1-10. 
366

367

368

369

370

371

372

373

374

375

376

377

378

379

380

381

382

383

384

Veggiani-Aybar CA, Dantur-Juri MJ, Claps G, Lizarralde de Grosso M, Spinelli G. $2015 a$. Latitudinal gradient of biting midges in the genus Culicoides (Diptera: Ceratopogonidae) in Argentina and Bolivia. Florida Entomologist 98 (2): 633-638.

Veggiani-Aybar CA. 2015b. Contribución al estudio de la fauna autóctona de Ceratopogonidae (Diptera: Nematocera) de las Yungas de la Argentina y Bolivia. Serie Monográfica y Didáctica 54: 198-198.

Veggiani-Aybar CA, Dantur-Juri MJ, Zaidenberg M. 2016. Mansonella ozzardi in Neotropical region of Argentina: Prevalence over time (1986-2010). Acta Tropica 153: 16.

Werner D, Kampen, H. 2010. The identification of Allohelea Kieffer and Allohelea tessellate (Zetterstedt) (Diptera: Ceratopogonidae) a genus and a species new to The Netherlands. Studia Dipterologica 17: 103-108.

WHO. 2010. Control of the leishmaniasis: report of a meeting of the WHO Expert Committee on the Control of Leishmaniases, 22-26 March, Geneva. Available at http://apps.who.int/iris/bitstream/10665/44412/1/WHO_TRS_949_eng.pdf (accessed 31 March 2016).

Young AM. 1983. Seasonal differences in abundance and distributionof cocoa-pollinating midges in relation to flowering and fruitset between shaded and sunny habitats of the La Lola Cocafarm in Costa Rica. Journal of Applied Ecology 20: 801-828. 


\section{Figure 1}

Geographic distribution of sampling sites in Juan Bautista Alberdi Department, Tucumán.

$E C=$ El Corralito,$E B=$ El Baden,$Y A=$ Yánima, $B M=$ Bajo Marapa,$M C=$ Marapa Central. (from Maria G. Quintana; Date of map @ 2006 Google Earth) . 

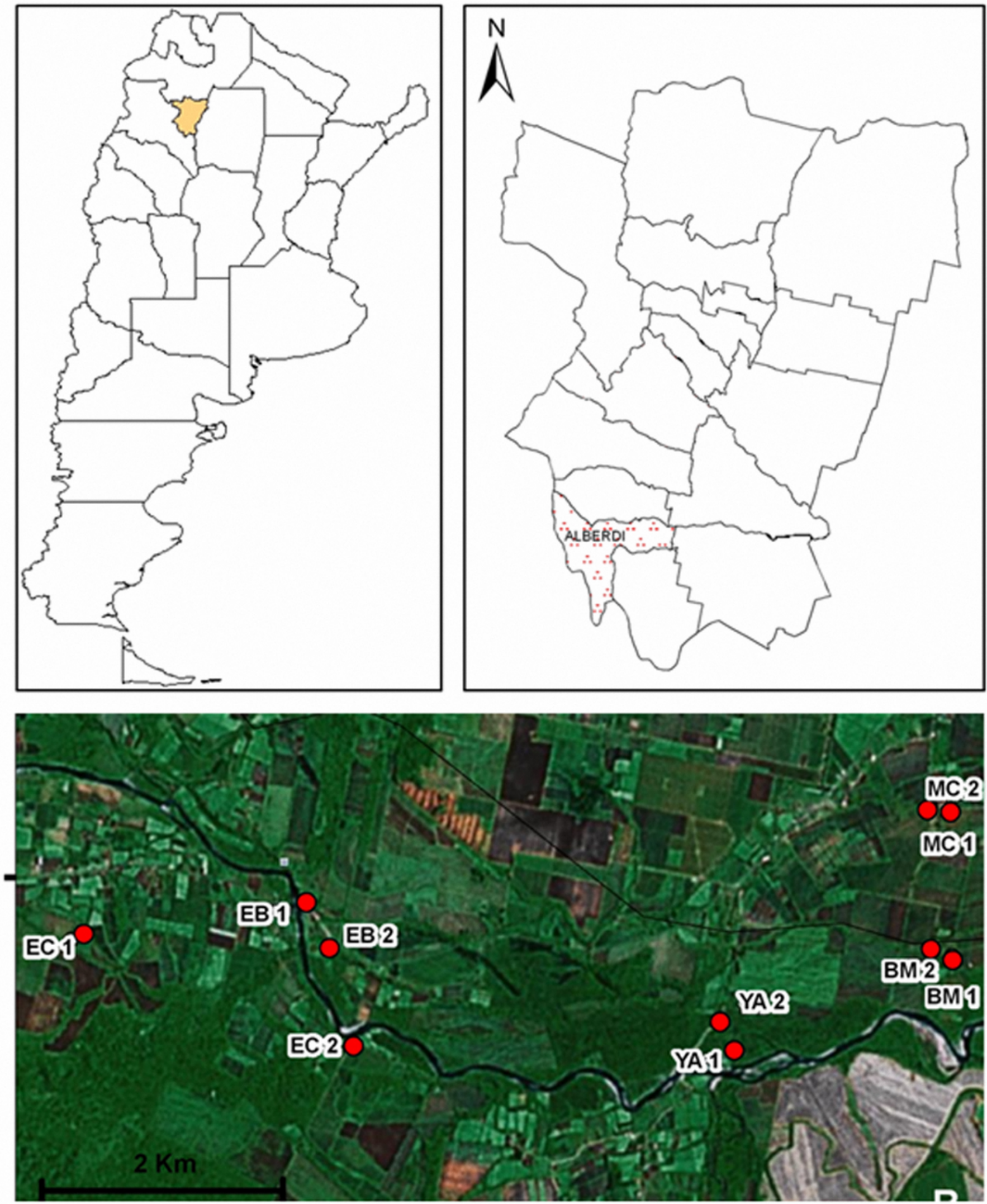
Figure 2

Mean relative abundance of A. Culicoides, B. Forcipomyia, C. Dasyhelea, D. Atrichopogon versus regressor variables.
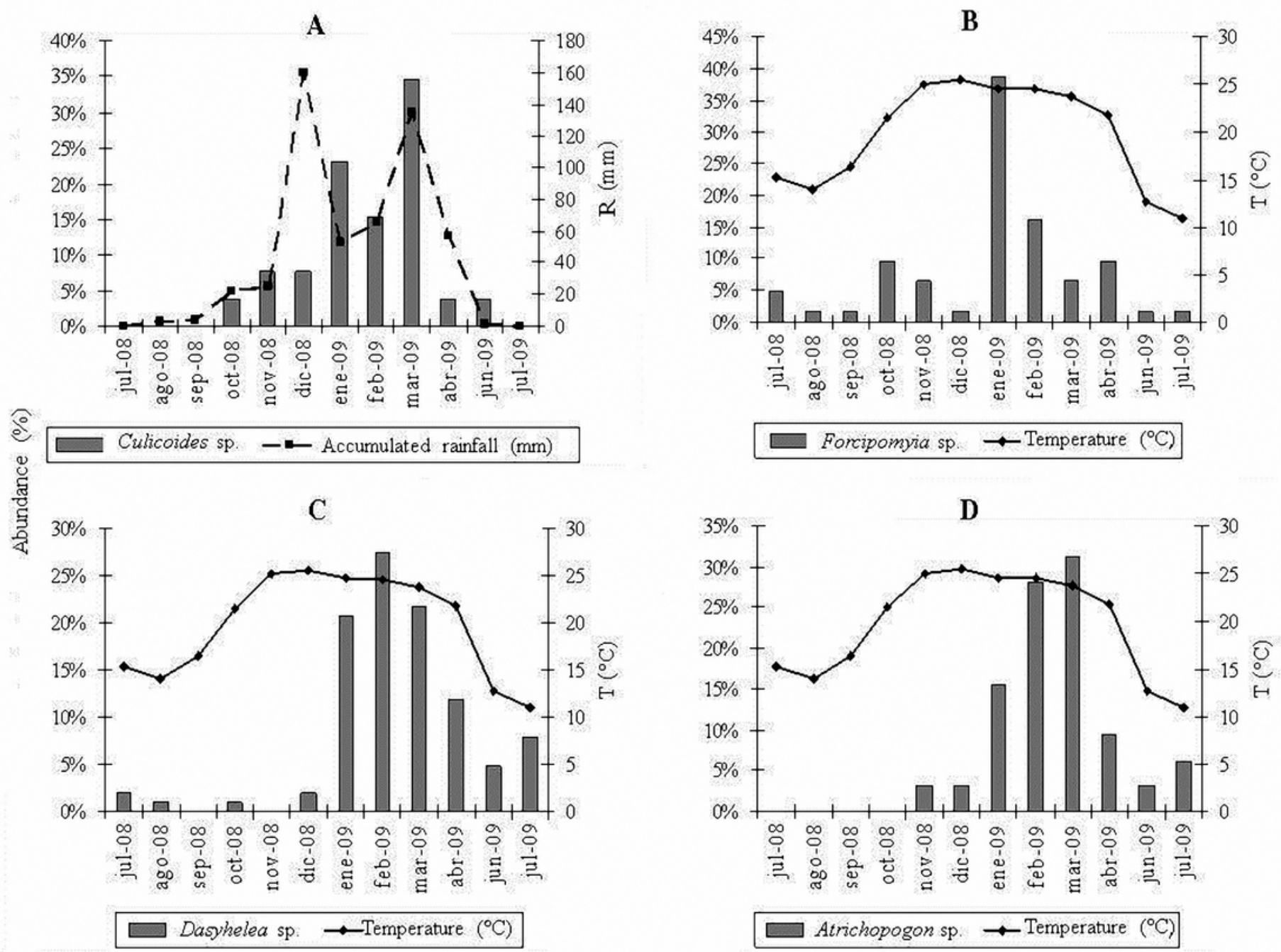
Figure 3

Partial residuals of A. Culicoides, B. Forcipomyia, C. Dasyhelea, D. Atrichopogon and retained variables by the statistical model.

A

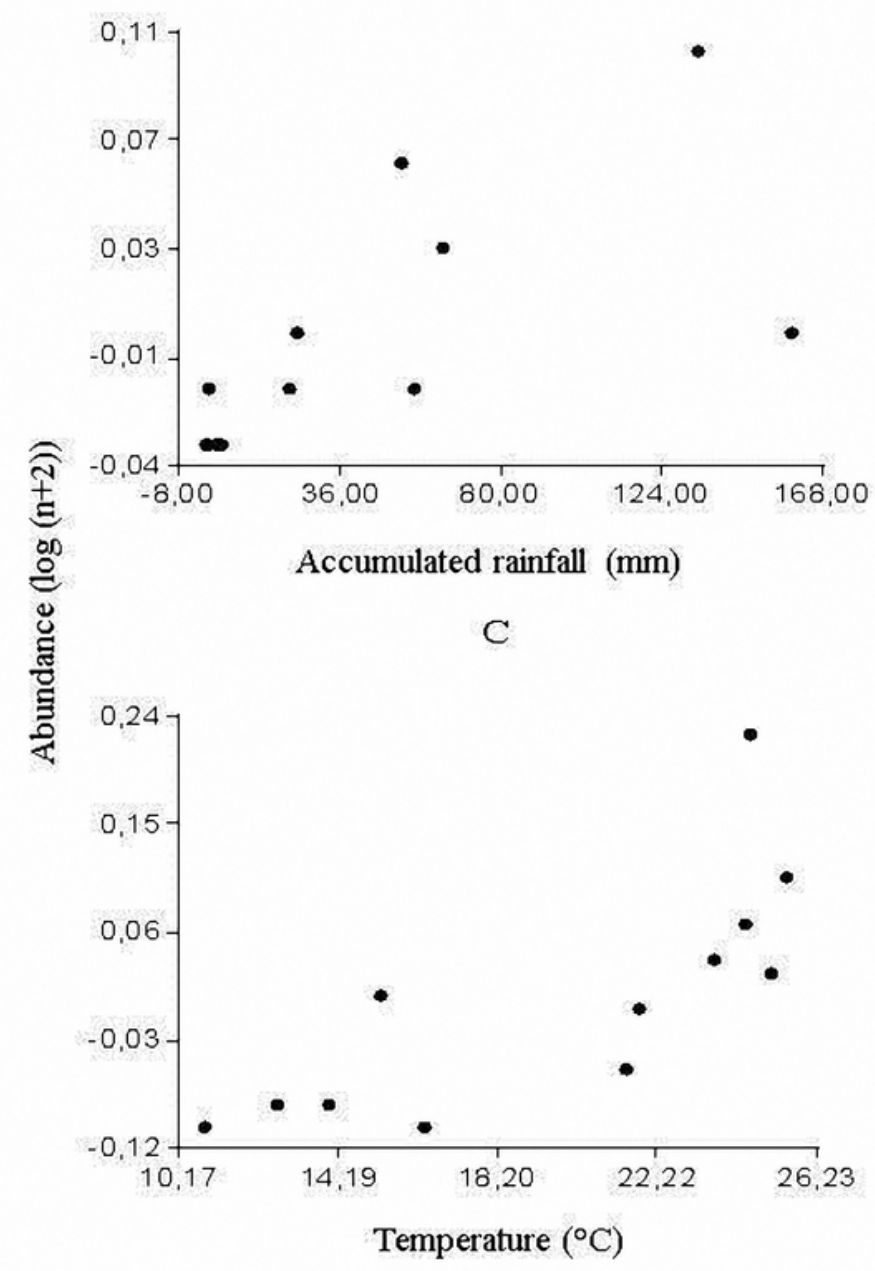

B

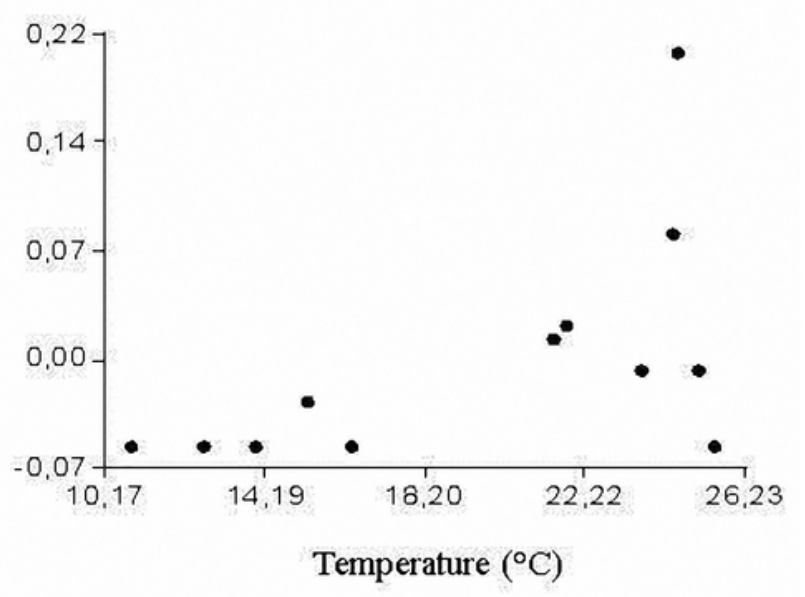

D

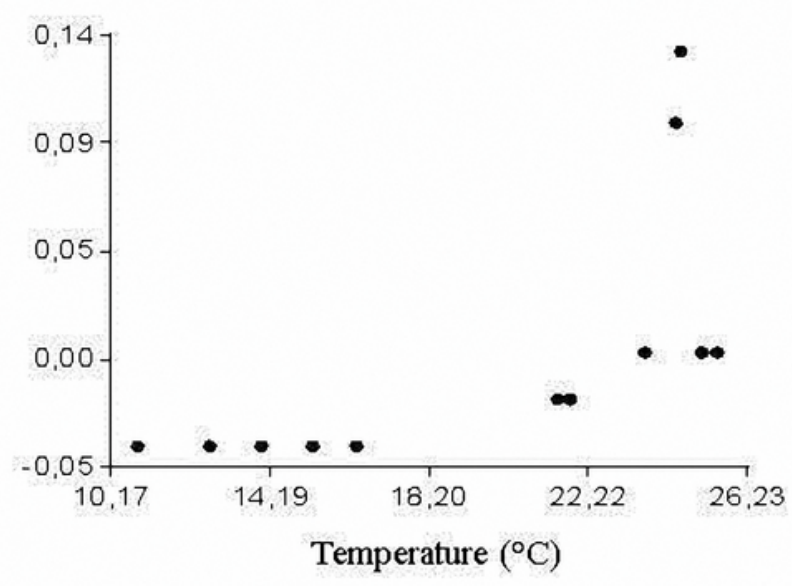


Figure 4

Standardized vs. predicted residuals for A. Culicoides, B. Forcipomyia, C. Dasyhelea, D. Atrichopogon.

A

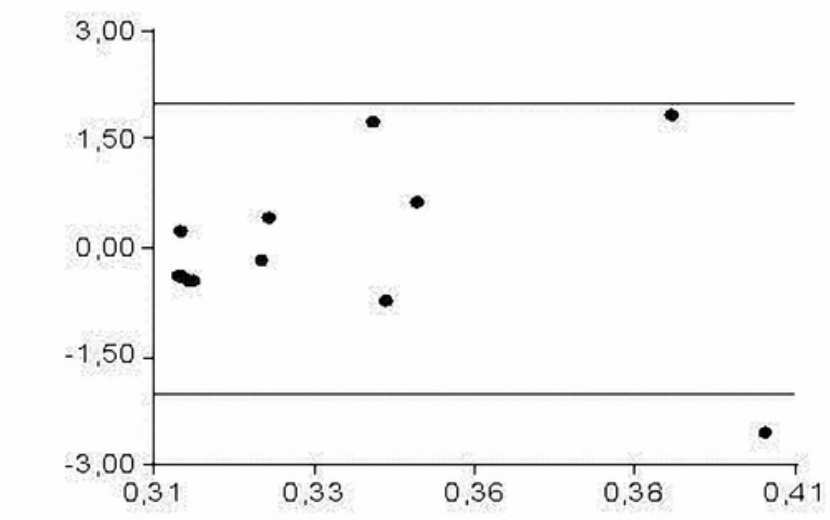

总

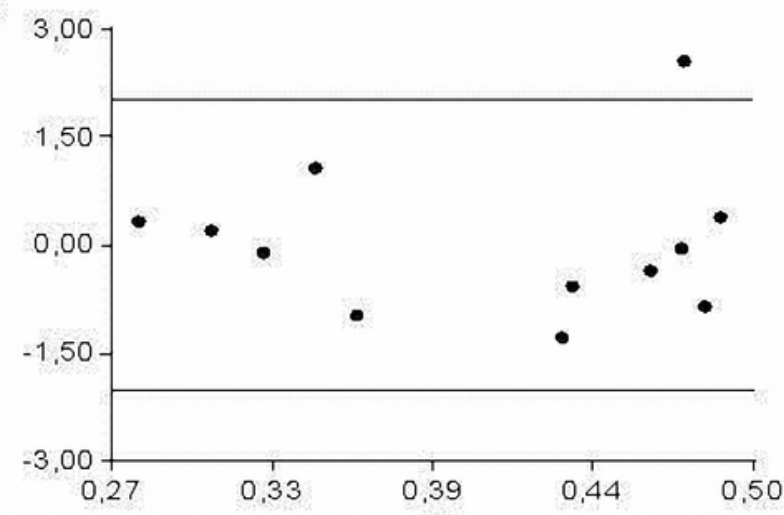

B

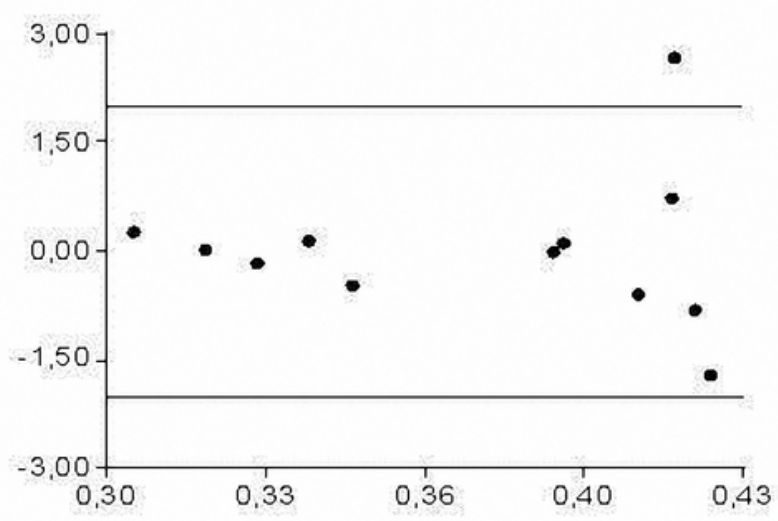

$\mathrm{D}$

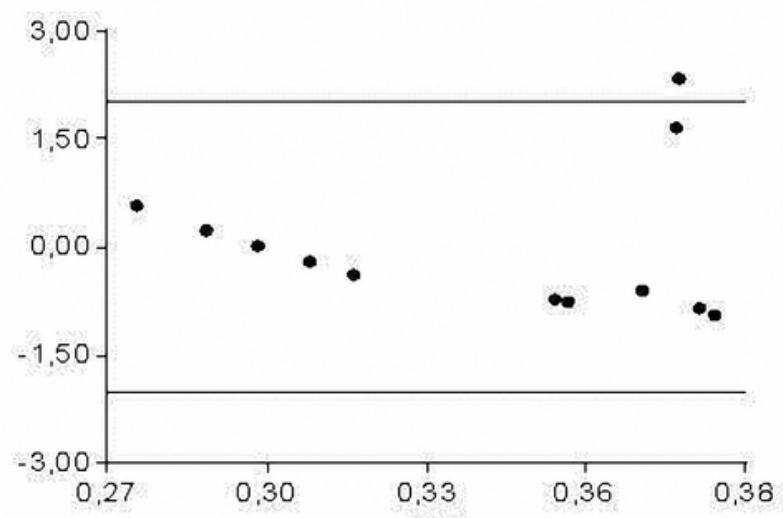

Predicted residuals 


\section{Table $\mathbf{1}$ (on next page)}

Absolute abundance of Ceratopogonidae during July, 2008- July, 2009, Juan Bautista Alberdi, Tucumán. 
1

\begin{tabular}{lccccccc}
\hline Genera & El Corralito & El Baden & Yánima & Bajo Marapa & Marapa Central & Total & (\%) \\
\hline Alluaudomyia & 1 & 0 & 0 & 0 & 0 & 1 & 0.28 \\
Atrichopogon & 22 & 15 & 2 & 7 & 3 & 49 & 13.61 \\
Bezzia & 1 & 0 & 0 & 0 & 0 & 1 & 0.28 \\
Culicoides & 16 & 12 & 4 & 2 & 4 & 38 & 10.56 \\
Dasyhelea & 74 & 26 & 14 & 17 & 41 & 173 & 48.06 \\
Echinohelea & 1 & 0 & 0 & 0 & 0 & 1 & 0.28 \\
Forcipomyia & 32 & 11 & 22 & 14 & 19 & 97 & 26.94 \\
\hline Total & 147 & 64 & 42 & 40 & 67 & 360 & 100 \\
\hline
\end{tabular}

2 
Table 2 (on next page)

Chi-squared coefficient test table and V Cramer association coefficient for Ceratopogonidae, in relation to sampling sites and season. 
1

2

\begin{tabular}{lccccc}
\hline Rows x columns & Chi-squared & g.l & p-value & x of table & $\begin{array}{c}\text { Coef. V } \\
\text { of Cramer }\end{array}$ \\
\hline Sities x genera & 38.92 & 12 & 0.0001 & 21.02 & 0.16 \\
Seasons x genera & 28.31 & 9 & 0.0008 & 16.91 & 0.14 \\
\hline
\end{tabular}

3 


\section{Table 3(on next page)}

Total abundance of the most common genera of Ceratopogonidae per seasonal and sampling site, Juan Bautista Alberdi, Tucumán

Site 1 = El Corralito, Site $2=$ El Baden, Site $3=$ Yánima, Site $4=$ Bajo Marapa, Site $5=$ Marapa Central 


\begin{tabular}{cccccc}
\hline Sites & Season & Atrichopogon sp. & Culicoides sp. & Dasyhelea sp. & Forcipomyia sp. \\
\hline 1 & Autumn & 1 & 0 & 13 & 5 \\
& Winter & 0 & 0 & 3 & 2 \\
& Spring & 1 & 3 & 2 & 1 \\
& Summer & 20 & 13 & 57 & 23 \\
& Autumn & 0 & 1 & 3 & 0 \\
& Winter & 1 & 0 & 3 & 2 \\
& Spring & 1 & 1 & 1 & 8 \\
& Summer & 13 & 10 & 19 & 0 \\
3 & Autumn & 2 & 1 & 2 & 2 \\
& Winter & 0 & 0 & 5 & 1 \\
& Spring & 0 & 0 & 0 & 5 \\
& Summer & 0 & 3 & 7 & 0 \\
4 & Autumn & 1 & 0 & 3 & 2 \\
& Winter & 1 & 0 & 1 & 7 \\
& Spring & 2 & 1 & 0 & 2 \\
& Summer & 3 & 1 & 13 & 1 \\
\hline 5 & Autumn & 0 & 0 & 6 & 11 \\
& Winter & 0 & 0 & 1 & 5 \\
\hline & Spring & 0 & 2 & 1 & $\mathbf{9 7}$ \\
\hline
\end{tabular}

